\title{
The role of human capital in the digitalization of the country's agriculture
}

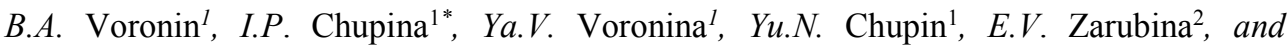 \\ N.N. Simachkova ${ }^{l}$ \\ ${ }^{1}$ Department of management and law, Ural State Agrarian University, 620075, Karl Liebknecht \\ st., 42, Yekaterinburg, Russia \\ ${ }^{2}$ Department of philosophy, Ural State Agrarian University, 620075, Karl Liebknecht st., 42, \\ Yekaterinburg, Russia
}

\begin{abstract}
Many agricultural enterprises in our country are working in crisis conditions. Therefore, the formation of human capital in modern conditions is a continuation of the strategic goals of the enterprise, where each enterprise has its own goals, performance and development prospects. Currently, distance education is considered on the same equal basis as fulltime education in higher education institutions. Intellectual and innovative activities become the main ones in training. That is why human capital is the main factor in the development of the enterprise. Currently, each company considers the tasks of personnel specialization. Each company is responsible for training and retraining its employees. The company is also responsible for reviewing issues related to the training or retraining of individual employees. Digitalization creates such opportunities - to learn remotely without interrupting production processes in their activities. Recently, online training has become popular, and the number of people on such courses continues to grow.
\end{abstract}

\section{Introduction}

Human capital has always been the main factor that ensures the efficiency and profitability of the organization. The problem is that in many enterprises, human capital is given a secondary role. The realization of an organization's potential depends on the knowledge, competence, qualifications, discipline, motivation, financial ability to solve problems, the level of receptivity to training of one staff and the level of management staff. Consequently, the personnel policy is the basis for the required management and production activities of the organization, as well as the effective selection of personnel, training and retraining is directed in full accordance with the modern technical needs of the company. The relevance of the research in this article is that the parameters of human capital are rapidly changing with the transition to digitalization. Rapid development of innovative processes requires employees to quickly learn new technologies, which is not always possible at all

\footnotetext{
*Corresponding author: irinacupina716@gmail.com
} 
enterprises. Therefore, in the article, the authors prove their idea that investment in human capital will fill the labor market with highly qualified personnel. Even J. Galbraith noted that the dollar in human capital brings a greater return than the dollar invested in production [12]. Gary S. Becker has researched issues related to human capital [6]. Currently, many foreign and Russian economists and sociologists are trying to prove the great role of human capital in the development of the economy.

\section{Purpose of the research}

The purpose of this study is to analyze the intellectualization of agricultural production and human capital. In the modern world, the digitalization of agriculture is already applicable in many agricultural enterprises, and the personnel potential, which is trained in innovative working methods, plays a great role not only in the development of a single enterprise, but also of the entire industry as a whole.

\section{Research objectives}

Agriculture solves the general tasks of its functioning, which are more focused on the implementation of three areas of activity:

1. Guaranteed food security in terms of production of high-quality agricultural products, raw materials and food produced by domestic agricultural producers in volumes corresponding to medical indicators.

2. Decrease in the volume of import substitution by seeds in crop production and breeding material in animal husbandry and poultry farming, as well as imported equipment for organizing food and processing products, veterinary preparations and other needs important for the agricultural sector.

3. Sustainable development of export of agricultural products and agribusiness to the global agri-food market.

These tasks cannot be successfully solved in the conditions of using existing obsolete agricultural technologies, machinery and equipment.

\section{Materials and methods}

The article uses materials from state statistics agencies at the federal and regional levels. The methods of analysis and synthesis are used to summarize the results of the study. The forecasting method is used in the proposals and recommendations of the authors for the formation of intellectualized human capital in agriculture.

\section{Research results}

Each enterprise is faced with the task of providing its employees with the necessary qualifications and certain skills with new technologies in the activities of the enterprise. It is no coincidence that it is now customary to say that staff is of paramount importance when considering the competitiveness of an enterprise.

The mechanism for the formation of the personnel strategy of a modern enterprise, taking into account the logical relationship between the overall strategy of the enterprise and the strategic directions of its personnel policy, implies a certain algorithm of actions 
that allows you to develop a comprehensive strategic plan for working with personnel taking into account the specifics of the enterprise, its goals and environmental parameters. Its essence is as follows. There is a general strategy of the enterprise, formed under the influence of external and internal factors, determines the basic functions of the enterprise, necessary for the implementation of the goals and, accordingly, forms functional strategies, which include the personnel management strategy.

The process of personnel strategy developing is complicated by a lack of financial, material, intellectual resources, and the level of professionalism of managers and specialists.

In the digital age, education will no longer be the same; it is taking a big leap forward. New information technologies are increasingly being introduced into training. As a result of this, the educational process in any educational institution becomes more flexible, with an individual approach to each student, who himself generates a request for knowledge and is included in the learning process at a convenient time for him. But at the same time, he loses personal communication with the teacher (Chupina I.P., 2016).

As a digital platform, you need to understand digital data, models and tools that are information and technology integrated into a single automated functional system, which is designed for qualified management of the target subject area in the interaction of interested parties in this.

Currently, new technologies are developing quite rapidly. In the first place universities should get the benefits of digitalization, as they will be able to provide more opportunities for applicants and students of this university during training. Each university is now choosing its own specifics of activity, trying to be cost-effective and competitive with other educational institutions.

The introduction of digital technologies in modern enterprises requires certain transformation processes within the entire enterprise. In a modern enterprise, data on operational processes within the enterprise gradually begin to implement computer databases, and all written documentation becomes obsolete.

Now in enterprises through the online system you can create various self-service systems. Many procedures already at some enterprises carry out programs - robots. But the use of new technologies depends on the financial investments of each individual enterprise. Companies that are more active in introducing new technologies are developing approximately $25-35 \%$ more profitably, unlike other enterprises. Those enterprises that have not yet chosen their digital platform in business lose to other competitors. Therefore, the digital economy is not built in one day, and is designed to pave the way for training, to create and increase human capital (Voronin and Fateeva 2014).

Table 1. Number of research and development personnel in the Sverdlovsk region (thousands)

\begin{tabular}{|l|c|c|c|c|c|c|}
\hline Numberofpersonnel & 2013 & 2014 & 2015 & 2016 & 2017 & 2018 \\
\hline Numberofemployees, total & 22,8 & 21,3 & 21,0 & 21,3 & 21,4 & 21,6 \\
\hline \multicolumn{7}{|c|}{ amongthem: } \\
\hline researchers & 9,3 & 9,2 & 8,5 & 9,8 & 9,6 & 9,4 \\
\hline technicians & 2,4 & 2,1 & 2,4 & 1,9 & 2,3 & 2,7 \\
\hline supportstaff & 7,6 & 6,9 & 7,2 & 6,8 & 6,9 & 7,1 \\
\hline otherpersonnel & 2,5 & 3,1 & 2,9 & 2,8 & 2,6 & 2,4 \\
\hline
\end{tabular}

It is enough to note that the yield of cereals and other agricultural plants is almost 1.5 2 times lower than the average in the European Union, USA, Canada and other European countries. The same applies to agricultural livestock productivity. 
Labor productivity, as the most important indicator of the economic efficiency of the agricultural sector, is 4-4.5 times lower in Russian agribusiness than in advanced foreign countries.

There is a noticeable difference in other economic indicators - profit, profitability, cost and others.

Obviously, in order to equalize the indicators, and even more to switch to the leading positions in the world, it is necessary to transfer Russian agriculture to scientific and technological development, which is based on the intellectualization of agricultural production and breakthrough areas of agricultural activity using nano - technologies, bio technologies and information technologies.

To successfully solve such problems, there will also be required the formation of an appropriate level of human capital.

Intellectualization, as defined by the Large Dictionary of the Russian Language, is an increase in the role of intelligence, an increase in the intellectual level (in our case, agricultural production) (Kuznetsov, 1998).

The Russian Encyclopedic Dictionary on page 581 defines intelligence as cognition, understanding, ability to think, rational knowledge (Russian Encyclopedic Dictionary, 2009).

In the newest dictionary of foreign words and expressions on page 345, intelligence is defined as the mind, reason, and intellectual ability of a person (Shagalova, 2017).

Intellectual is a skill that comes from the mind, it is a spiritual level capable of analytical activity.

Intellectualization of economic activity is the most important direction in the development of the agricultural economy.The practical implementation of the areas of intellectualization lies in the development of Smart Agriculture, which is based on the project of the Ministry of Agriculture of Russia "Digital Agriculture".

One of the main innovations of the project is the digital platform "Digital Agriculture", which presents a fairly large information database on agricultural resources. Most of the project budget will be allocated in the form of grant support to farms that will invest for their own modernization.

It is also planned to develop three integrated digital solutions that will be implemented in agriculture.

The first direction - this is a "smart farm" - it is a robotic agricultural facility designed to breed animals in an automatic mode that does not require human intervention. "Smart Farm" independently conducts an analysis of the economic feasibility of production, consumer activity, the level of public health and other economic indicators. For this there are used Internet data, neural networks. Based on the data, the "farm" makes decisions about which species and breeds of animals (with given qualitative and quantitative indicators) must be bred (Voronin et al., 2017).

Such technologies will help to increase the level of production and consumption of dairy products in the country. Depending on the microclimate and the condition of the animals on the farms, automated systems will help improve the quality of milk to the "extra" class and ensure a constant increase in the milk production of animals.

The second direction is the "smart field", which is a system that automatically analyzes information on the state of agrobiocenosis. Then this system makes decisions and implements these decisions using robotic hardware. This includes an analysis of soil and climatic conditions, determining the choice of crops depending on specific goals, maximizing production or profitability, and regulating plant nutrition.

The third area is the "smart greenhouse". It is also a robotic object that is isolated from the external environment to receive crop products in automatic mode. Here the participation of the operator and the agronomist is minimal. This system works in compliance with 
environmental and sanitary - hygienic requirements and uses digital technologies taking into account the agroecological assessment of hybrids and plant varieties, soil analysis. The introduction of such technologies will ensure a stable growth of crop production in greenhouses and will allow to obtain high quality products. Reduce the energy intensity of production and increase the nutritional value of vegetables (Chupina, 2017).

Along with the above-mentioned "smart farming" projects, other digital agronomic projects are being prepared for use, such as "smart herd", "smart processing", "smart warehouse", "smart agricultural office", "smart agricultural enterprise", "Smart land use", "smart garden", "smart region", digital technologies in agricultural management and others (Chupina, 2016).

As the name of the projects shows, agricultural intellectualization is based on the application of decision-making systems for integrated automation and production robotics, as well as ecosystem design and modeling technologies. It involves minimizing the use of external resources such as fuel, fertilizers and chemicals while maximizing the use of factors such as biofuels, organic fertilizers and others.

Promising technologies of "intelligent" agriculture will ensure effective environmentally friendly pest control; will help restore and preserve the beneficial properties of soils and groundwater, and using these technologies will constantly monitor compliance with certification requirements of organic agriculture. Such technologies include biopesticides for pest control, nanobiotechnological remediation of water and soil, integrated control systems in agricultural production (Voronin, et al., 2019).

By order of the Government of the Russian Federation No. 1632-r dated July 28, 2017, the Digital Economy of the Russian Federation Program was approved (Order of the Government of the Russian Federation, 2017).

The implementation of this program is based on goals and objectives, directions and timelines for the main measures of the state policy of the Russian Federation to create conditions for the development of the digital economy in the country.

Table 2. Indicators of innovative activity of organizations for 2016-2018

\begin{tabular}{|c|c|c|c|}
\hline Indicators & 2016 & 2017 & 2018 \\
\hline Innovation costs, million rubles & 52623,1 & 45038,7 & 39880,5 \\
\hline \multicolumn{4}{|c|}{ among them: } \\
\hline technological innovation & 52454,1 & 44762,0 & 39781,2 \\
\hline marketinginnovation & 6,2 & 18,0 & 4,5 \\
\hline organizationalinnovations & 162,8 & 258,7 & 94,8 \\
\hline $\begin{array}{l}\text { The share of innovative goods, works, } \\
\text { and services in the total volume of goods } \\
\text { shipped, works performed, and services } \\
\text { rendered, \% }\end{array}$ & 8,4 & 10,3 & 6,9 \\
\hline
\end{tabular}

In order to implement the Strategy for the Development of the Information Society in the Russian Federation for 2017-2030, approved by the Decree of the President of the Russian Federation dated May 9, 2017 "On the Strategy for the Development of the Information Society in the Russian Federation for 2017-2030", this program is aimed at creating conditions for the development of society knowledge in the country, improving the well-being and quality of life when using digital technologies, increasing digital literacy among the population (Decree of the President of the Russian Federation dated 09.05.2017).

Table 3. Number of personnel involved in research activities by field of science (people)

\begin{tabular}{|l|l|l|l|l|l|l|}
\hline Numberofresearchers & 2013 & 2014 & 2015 & 2016 & 2017 & 2018 \\
\hline
\end{tabular}




\begin{tabular}{|l|c|c|c|c|c|c|c|c|}
\hline Totalnumberofresearchers & 11427 & 11728 & 12749 & 12406 & 12016 & 12056 \\
\hline \multicolumn{7}{|c|}{ Of them by field of science: } \\
\hline naturalscience & 2010 & 2036 & 2154 & 2199 & 2136 & 2183 \\
\hline technicalscience & 5641 & 5798 & 6198 & 6234 & 6079 & 6068 \\
\hline medicalscience & 199 & 213 & 189 & 176 & 186 & 193 \\
\hline agriculturalscience & 165 & 221 & 169 & 169 & 179 & 181 \\
\hline socialscience & 538 & 485 & 670 & 568 & 457 & 460 \\
\hline humanities of & 215 & 311 & 358 & 309 & 299 & 238 \\
\hline $\begin{array}{l}\text { Out of the number of } \\
\text { researchers doctors of science }\end{array}$ & 648 & 651 & 706 & 656 & 646 & 682 \\
\hline $\begin{array}{l}\text { Out of the number of } \\
\text { researchers candidates of } \\
\text { science }\end{array}$ & 2011 & 2013 & 2305 & 2095 & 2034 & 2051 \\
\hline
\end{tabular}

In order to coordinate managerial actions in the field of the digital economy, the Government of the Russian Federation No. 234 dated March 2, 2019 (Decree of the Government of the Russian Federation, 2019). approved the Regulation on the system for managing the implementation of the national program "Digital Economy of the Russian Federation". This provision approved the organizational structure of bodies involved in the implementation of the Digital Economy of the Russian Federation Program.

The responsibility for the implementation of this program lies with the Ministry of Digital Development, Telecommunications and Mass Media of the Russian Federation. The functions of the project office for the implementation of the program are carried out by the autonomous non-profit organization "Analytical Center under the Government of the Russian Federation".

The development of the digitalization level of the economy is of scientific and practical interest among scientists and specialists. As an example, we can cite the scientific publication of Doctor of Laws, Professor B. Voronin, and Doctor of Economics, Professor A. N. Mitin, "Management of the Digitalization of Agriculture" (Voronin and Mitin, 2018).

Here are excerpts from this article: "Management tasks are related to the training of professionals and specialists who would be involved in the implementation of digitalization technologies in practice.It will require not only the systematization of large databases by them, but also the creation of new forms of artificial intelligence, bots and robots.Taking into account that Russia is inferior to other countries in the level of penetration of information technologies in agriculture, the work ahead is architruded with appropriate funding. It will be necessary to improve qualifications for all, without exception, agronomists, livestock specialists, managers, and to attract new specialists and scientists.

Therefore, new cadres - highly trained and knowledgeable in modern information technologies for intellectualized agriculture - play a paramount role (Vartanova, 2017).

The goal of the personnel policy of the organization's literature is to ensure a balance between the economic and social side as the use of human capital, the timely provision of options near the departments was motivated by qualified employees, creating conditions for efficient use and development of the intellectual potential of the company's personnel, satisfying not only socio-high economic interests of employees, but also the possibility of obtaining assistance from the organization and retraining and continuing education.

Thus, the main goal of personnel policy is the timely selection of highly qualified personnel, the development of human capital, increasing human production efficiency through informatization and modernization of production in each individual agricultural enterprise.

The existence of agricultural enterprises in reserve conditions of a competitive market causes the frequency of the need to implement a staff development strategy, as one of the 
main components needed.Developing an organization's personnel strategy is a difficult task, within which the central place is occupied by the problem of achieving strategic compliance for each employee.Strategic integration is necessary to give integrity to the message of the overall organizational personnel strategy. The overall goal of this process is the intellectualization of human capital and the transition to digital agriculture.

At the end of the 1990s, large agricultural enterprises appeared in the country agricultural holdings. Already after 8-10 years, these enterprises have the opportunity to invest their funds in innovation. In agriculture, soil sensors are becoming the new digital element. Due to this, agronomists were able to obtain the necessary information from the fields.

In the crop industry, new digital technologies have made it possible to clarify the condition of the fields, which is very important for farmers. These technological innovations indicate the timing of planting, the amount of watering, fertilizer application. Using the same drones, it becomes possible to find out the state of the soil, and, therefore, determine how much fertilizer and watering is required for a given site.

With the help of new technologies, agricultural machines have the opportunity to apply the required amount of fertilizer, selecting these fertilizers for specific fields. Such technologies can be used on any agricultural land, and the economic effect can be approximately 300 million rubles per 100 thousand hectares.

The first robotic factory appeared in Russia, where are produced a smoked sausages "Cherkizovo". Instead of 700 workers, the factory is engaged in production only 150 and this enterprise will be able to provide $30 \%$ of the country with smoked sausages.

Already, investors are starting to invest in innovative projects in the agricultural sector.For example, the Swiss company EcoRobotix has developed a robot that weeds out.In Germany and Denmark are being developed robotic systems for precise spraying and irrigation.Now many developed countries have many startups for agriculture.Work on a single digital platform will reduce the cost of resources and get the opportunity to cheaper resources.

But in order to apply these technologies in the work of enterprises, we need qualified personnel.In modern society, informatization is especially relevant.The knowledge aimed at modeling and modernizing the labor process directly depends on human capital.The level of development of informatization and digitalization in different regions of the country is not the same.One of the indicators is the development of infrastructure in each individual region.The most necessary statistics data are obtained from Rosstat, the Ministries of Health, Finance and Education and other sources. The data are carried out on 72 indicators, which are divided into 11 groups according to the main categories of living conditions in the region. First of all, of course, here it is necessary to study the level of development of the innovative structure of the region. Then comes the accessibility of population education in the region. Further is human capital as a productive factor, which is a professional retraining, science, information.

But here it is necessary to note certain difficulties, to which we attribute primarily the uneven development of social infrastructure in the region. This gives rise to internal migration of the population.

As an example, we cite the Taborinsky district, where in the middle of the 20th century the population of the district was 20 thousand people. Now there are only 3100 permanent residents. There are only three villages on the territory of more than 11 thousand square kilometers. In the Garinsky district, the situation is no better. This area occupies 16,000 square meters. kilometers. And only 4 thousand people live in this area.

Currently, in the Sverdlovsk region, there are more than 150 abandoned villages and towns (Russian statistical yearbook, 2018). 
According to statistics, more than 20 villages drop out of the lists of rural settlements of the Sverdlovsk region annually. Over the past 10 years, according to the Institute of Economics, approximately 800 rural settlements have disappeared without a trace in the Sverdlovsk Region (Rosstat. Report on Agriculture for 2018).

And now, residents of small cities and towns, which are located at a distance of $40-100$ kilometers from Yekaterinburg, are ready to go to work every day to the city. There is an internal migration. Many work on a rotational basis if they cannot solve the housing problem.

In 2019, migration processes improved. The growth of the migration population in the region increased, and the outflow from the region decreased and amounted to 1322 people in 2019. The migration growth of the region's population amounted to three thousand people in 2019.

What are the factors that determine human capital? First of all, we attribute to them the ability to learn and perceive new information; level of professional qualifications and professional education; professional skills developed in the process of work and experience; social skills, intellectual and analytical skills.

\section{Conclusions}

Thus, as human capital we can name the educational potential of each individual person, which positively affects his production potential.

Again, we must take into account such a factor as economically active age.It includes business and creative activity, professionalism and innovation. Of course, one cannot say about every person that with age he loses his ability to work and innovate, but in most cases this is manifested.Therefore, basically the development of human capital is inherent in the young generation. And the task of preserving human capital is of strategic importance.

We have already said above that investment in the agricultural sector is beginning to increase and become profitable. The introduction of digitalization for "smart farms", "smart greenhouses" and other projects is planned to be carried out with the help of large companies that specialize in working with information technology.

A summary of the tasks that are proposed to be solved in the coming years in the implementation of the Digital Economy of the Russian Federation Program is that the formation of human capital for working in the conditions of intellectualized agriculture is in demand.For agricultural universities, it will be important to introduce the new discipline "Digital Agriculture" into the educational process. But for this it is necessary to create modern computer classes, to study the latest digital platforms and Internet accelerators.

The future personnel for agricultural enterprises in the majority live in rural areas. Therefore, it is important to create conditions for the intellectual development of youth in rural schools.

Digitalization, creating the conditions for the development of "smart agriculture", undoubtedly affects the progress in agricultural relations.But we must not forget about human rights, which can be seriously violated if the conditions for the existence of human capital in new innovative conditions are not created (Voronin et al., 2019).

It is obvious that it is necessary to develop a system for retraining personnel, organize labor discipline of rural residents in small forms of management, and find alternative forms for the production activities of the rural population.

Recently, positive changes have been taking place in the program for digitalizing the economy in the country. These changes largely depend on the further development of human capital.Now digitalization should take place at an innovative level, at which every person can have access to information systems. This will make the life of every person more fulfilling and of high quality. Investments in the development of innovative processes 
of the economy and agribusiness in particular will fill the labor market with highly qualified personnel.

\section{References}

1. D.A. Bachin, Modern Research and Innovation, 23, 19-21 (2017)

2. T.A. Boronenko, A.V. Kaysina, V.S. Fedotova, , Prospects for science and education, 2 (38), 167-193 (2019). URL: https://cyberleninka.ru/article/n/razvitie-tsifrovoygramotnosti-shkolnikov-v-usloviyah-sozdaniya-tsifrovoy-obrazovatelnoy-sredy

3. I.P. Chupina, Formation of the general marketing strategy of a university as a choice of educational services strategy, Science today: theory, practice, innovation. Collection of the XI International scientific-practical conference, 976-979 (2016)

4. I.P. Chupina, International Journal of Environmental and Science Education, 11 (15), 7754 - 7762 (2016)

5. I.P. Chupina, System of State Order for Agricultural products in Russia and Foreign Countries, Overcoming Uncertainty of Institutional as a Tool of Global Crisis Management, Springer international Publishing AG, 437-441, (2017)

6. Gary S. Becker, Human behavior: an economic approach. Selected papers on economic theory, 672, (Moscow: Publishing house of the higher school of Economics,2003)

7. Decree of the President of the Russian Federation dated 09.05.2017, № 203On the Strategy for the Development of the Information Society in the Russian Federation for 2017 2030.

URL: http://publication.pravo.gov.ru/Document/View/0001201705100002

8. Decree of the Government of the Russian Federation of March 2, 2019, № 234 (as amended on December 7, 2019) On the system for managing the implementation of the national program Digital Economy of the Russian Federation. URL: www.pravo.gov.ru, December 11, 2019, № 0001201912110009

9. Informatization of education, Russian Pedagogical Encyclopedia (2019). URL: https://pedagogicheskaya.academic.ru/1241/

10. T.A. Filippova, G.S. Frolova, The essence and objectives of the personnel policy and personnel strategy of the enterprise, Humanitarian research, 12, 39-42 (2016)

11. S.A. Kuznetsov, The large explanatory dictionary of the Russian language, 1534 (Ch. ed. First edition: St. Petersburg: Norint1998(published in the 2014 copyright edition))

12. J.K. Galbraith, Economic theory and goals of society, 270 (TRANS. with English-M.: «Progress», 1976)

13. Order of the Government of the Russian Federation of July 28, 2017, № 1632-r On approval of the program Digital Economy of the Russian Federation

14. K.A. Perezhogina, Young scientist, 4, 403-408 (2015)

15. A.A. Rabtsevich, The mechanism of innovative orientation of labor resources in the economy of the region, Scientific reports of BelSU. Series: Economics. Computer science, 8, 58-70 (2014)

16. Research of the Russian market of online education and educational technologies URL: https://edmarket.digital/

17. Rosstat. Report on agriculture for 2017

18. Rosstat. Report on agriculture for 2018

19. Russian Encyclopedic Dictionary, Rep. ed.(Gold Fund. Encyclopedic Dictionary), 1887, (Moscow: Big Russian Encycl., 2009)

20. Russian statistical yearbook. 2017: Stat.sb. 796 (Rosstat. M., 2018)

21. Russian statistical yearbook. 2018: Stat.sb. (Rosstat. M., 2019)

22. E.N. Shagalova, Dictionary of the newest foreign words: (detailed etymological reference), 345 (Moscow: AST-PRESS, 2017) 
23. The main trend of Russian education is digitalization. URL: http://www.ug.ru/article/1029

24. A.E. Sirchenko, Young scientist, 12, 496-499 (2015)

25. E.L. Vartanova Industry of the Russian media: the digital future: an academic monograph, 160 (M.: MediaMir, 2017).

26. B.A. Voronin, I.P. Chupina, Y.V. Voronina, , Agrarian Bulletin of the Urals, 3 (182), 52-57 (2019)

27. B.A. Voronin, I.P. Chupina, Y.V. Voronina, Digitalization as a modern learning mechanism in educational institutions, Social and humanitarian education in the modern world: problems, searches, solutions, 52-59 (2019)

28. B.A. Voronin, I.P. Chupina, A.L. Pustuev, A.N. Semin, N.A. Potekhin, Journal of Advanced Biotechnology and Research (IJBR), 8 (4), 1363-1369 (2017) URL: http://www.bipublication.com

29. B.A. Voronin, I.P.Chupina, V.M. Sharapova, V.V. Maslakov, M.V. Fedorov,E.M. Cot, A.G. Mokronosov, Federal The Turkish Online Journal of Design, Art and Communication, TOJDAC. Special Edition, 2102 (2017)

30. B. A. Voronin, I. P. Chupina, E.M. Kot, A.G. Mokronosov, International journal of Advanced Biotechnology and Research (IJBR), 9 (1), 1023-1028 (2019). URL:http://www.bipublication.com

31. B. A. Voronin, A. N. Mitin, Agrarian Bulletin of the Urals, 5, 61-69 (2018)

32. B. A. Voronin, N. B. Fateeva, Agrarian Bulletin of the Urals, 11, 60-62 (2014) 